\title{
Making Sense of the \\ McDonnell Douglas Framework: \\ Circumstantial Evidence and Proof of Disparate Treatment Under Title VII
}

\author{
Țristin K. Green $\dagger$
}

Congress enacted the Civil Rights Act of 1964 to combat racism in America. The Act has since served as an important tool in fighting discrimination in the workforce. In particular, Title VII of the Act provides that a person's protected group status must be irrelevant to employment decisions. Title VII's effectiveness has been diluted, however, by confusion surrounding the overarching framework and methods of proof available to a plaintiff who relies on circumstantial evidence to prove his case. Because discrimination today is rarely overt, a coherent framework for identifying discrimination in its more subtle forms through circumstantial evidence is essential if Title VII is to retain its force. This Comment proposes such a framework. It argues that the McDonnell Douglas framework, created by the Supreme Court in 1973 to aid in adjudicating individual disparate treatment claims based on circumstantial evidence, encompasses two already-recognized methods of proof as alternate methods through which the plaintiff can establish an inference of discrimination. In doing so, it sets out a novel interpretation of the relationship between the existing framework and methods of proof, and provides renewed strength to an oftused but poorly understood doctrine.

\section{INTRODUCTION}

A plaintiff files a claim in federal court in each circuit of the United States against his enployer for firing him on the basis of race in violation of Title VII of the federal Civil Rights Act. He lacks a statement by his employer that the company fired him because he is black, but he has

Copyright $\odot 1999$ California Law Review, Inc.

$\dagger$ J.D., School of Law, University of California, Berkeley (Boalt Hall), 1998; Law Clerk, Honorable Garland E. Burrell, Jr., Eastern District of California (1998-1999); Law Clerk, Honorable Dolores K. Sloviter, United States Court of Appeals for the Third Circuit (1999-2000). I would like to thank Professor Linda Hamilton Krieger for her suggestions and encouragement. 
substantial circumstantial evidence to support his claim, including a number of race-based slurs made by his supervisor. Despite the fact that this plaintiff filed his claim under federal law in federal court, his claim will be analyzed in numerous and conflicting ways. The problem lies not in the merit of his case, but $m$ the misunderstood frainework under which his disparate treatment claim is to be adjudicated.

Title VII of the Civil Rights Act of 1964 prohibits discrimination in employment on the basis of race, sex, color, religion, and national origin.' The Act prohibits two general types of discrimination: disparate impact discrimination, in which a neutral practice has discriminatory effects, and disparate treatment discrimination, in which an employer intentionally discriminates against a particular person or group of persons. ${ }^{2}$

The Supreme Court once described disparate treatment discrimination as "the most easily understood type of discrimination." 3 While this may have been true twenty or thirty years ago, today disparate treatment litigation opens multiple corridors of complexity. Not long ago, Congress enacted the Civil Rights Act of $1991,{ }^{4}$ amendments to Title VII intended to clarify confused doctrine and to establish a coherent frainework within which Title VII claims could be analyzed and adjudicated. Six years later, the framework and methods of proof for proving disparate treatment under Title VII remain in a state of chaos. It need not be so.

This Comment seeks to clarify the methods of proof available for a claim of individual disparate treatment under Title VII in light of Supreme Court doctrine and the Civil Rights Act of 1991. It proposes that the two currently recognized inferential methods of proof for proving intentional discrimination, termed here the "motivating-factor" method of proof and the "falsity-of-proffered-reason" method of proof, are available as alternate methods within the Court's overarching McDonnell Douglas framework. In doing so, it reveals that continued lower court reliance on a distinction between these two available methods of proof based on the type or strength of evidence presented by a plaintiff is gravely misplaced. Part I begins by tracing a brief background of the overarching McDonnell Douglas

1. 42 U.S.C. $\$ 2000 \mathrm{e}-2$ (1994). Section 703(a) of Title VII states:

It shall be an unlawful employment practice for an employer-

(1) to fail or refuse to hire or to discharge any individual, or otherwise to discriminate against any individual with respect to his compensation, terms, conditions, or privileges of employment, because of such individual's race, color, religion, sex, or national origin .... 42 U.S.C. $\$ 2000 \mathrm{e}-2$ (a).

2. Although Title VII currently prohibits both disparate impact and disparate treatment discrimination, its primary purpose at inception was the elimination of intentional discrimination in the work force. See International Brotherhood of Teamsters v. United States, 431 U.S. 324, 335 n.15 (1977) ("Undoubtedly disparate treatment was the most obvious evil Congress had in mind when it enacted Title VII."). Disparate impact discrimination was recognized as a Title VII violation by the Supreme Court in Griggs v. Duke Power Co., 401 U.S. 424 (1971).

3. Teamsters, 431 U.S. at 335 n. 15.

4. Pub. L. No. 102-166, 105 Stat. 1071 (1991) (codified in scattered sections of 42 U.S.C.). 
framework and the two inferential methods of proof as they have been articulated by the Supreme Court, interpreted by lower courts, and amended by the Civil Rights Act of 1991. This Part also examines the more recent lower court interpretation of the 1991 Act itself. Part II then argues that a coexistent relationship between the two methods of proof within the overarching McDonnell Douglas framework is not only consistent with prior case law and congressional intent, but makes practical sense.

I

\section{BACKGROUND AND CURRENT INTERPRETATION}

Under current law, to prevail on a disparate treatment claim under Title VII, a plaintiff must prove intentional discrimination. ${ }^{5}$ As with any claim, a plaintiff can do so with direct or circumstantial evidence. ${ }^{6}$ Changes in the nature of discrimination in the workforce since the enactment of the Civil Rights Act in 1964, however, have made direct evidence of intentional discrimination hard to produce. ${ }^{7}$ In response to those changes, in 1973 the Supreme Court promulgated a tripartite framework of proof for all cases of individual disparate treatment under Title VII in which the plaintiff relies on circumstantial evidence to prove his case. Further, in addition to the overarching tripartite framework, the Court has articulated two alternate inferential methods of proof for plaintiffs filing claims of disparate treatment under Title VII. There is no question that the tripartite framework and two methods of proof operate to define a plaintiff's claim of disparate treatment under Title VII; there is endless confusion, however, concerning the applicability of the methods of proof and their relationship to the overarching framework. Although it made several important changes to Title VII disparate treatment jurisprudence, the Civil Rights Act of 1991 has compounded the confusion.

5. See, e.g., St. Mary's Honor Ctr. v. Hicks, 509 U.S. 502, 507 (1993) (holding that the plaintiff has "the ultinate burden of persuading the trier of fact that the defendant discriminated against the plaintiff') (quoting Texas Dep't of Community Affairs v. Burdine, 450 U.S. 248, 253 (1981)).

6. Direct evidence is evidence that, if believed, resolves a matter at issue. See infra notes 118123 and accompanying text. Examples of direct evidence of disparate treatment include explicit discriminatory policies or statenents by an employer that an employnent decision was based on an impermissible factor. This evidence, if believed, proves discrimination. Circumstantial evidence, im contrast, is evidence from which the fact finder can infer a matter at issue. Racial slurs by a supervisor or evidence of a promotion of a white employee over a better qualified Hispanic employee might be circumstantial evidence of disparate treatment. See id. The terms "direct" and "circunstantial" evidence have become increasingly confused in disparate treatment jurisprudence. This Comment seeks to set the terms straight. See infra Part II.

7. See infra notes 125-126 and accompanying text. 


\section{A. The McDonnell Douglas Framework as Established by the Supreme Court}

The Supreme Court in McDonnell Douglas Corp. v. Green ${ }^{8}$ laid out a tripartite framework for the order and allocation of proof in Title VII individual disparate treatment cases based on circumstantial evidence. Under the McDonnell Douglas framework, the plaintiff must first establish a prima facie case of discrimination. ${ }^{9}$ Once the prima facie case is established, in order to avoid a verdict for the plaintiff, the employer must articulate "some legitimate, nondiscriminatory reason" for its decision. ${ }^{10}$ Finally, at the third stage, the plaimtiff must, in the words of the McDonnell Douglas Court, "be afforded a fair opportunity to show that [defendant's] stated reason for [plaimtiff's] rejection was in fact pretext."11

In McDonnell Douglas, plaimtiff Green, a black man, had been laid off from his job as a mechanic by defendant McDonnell Douglas Corporation. ${ }^{12}$ Upon being laid off, he protested that his discharge and the general hiring practices of McDonnell Douglas were racially discriminatory. As part of the protest, he participated in a stall-in at one of the McDonnell Douglas plants, where he was arrested for obstructing traffic. ${ }^{13}$ McDonnell Douglas subsequently publicly advertised for qualified mechanics. ${ }^{14}$ Green applied for a position, but was turned down on the basis of his participation in the stall-in. ${ }^{15} \mathrm{He}$ brought suit for race discrimination and retaliation under Title VII. ${ }^{16}$

In applying its tripartite framework, the McDonnell Douglas Court first found that Green had established a prima facie case. ${ }^{17}$ It explained that in a hiring case the plaintiff may establish a prima facie case by showing:

8. 411 U.S. 792 (1973).

9. See id. at 802 .

10. Id. ("The burden then must shift to the employer to articulate some legitimate, nondiscriminatory reason for the employee's rejection.").

11. Id. at 804 .

12. See id. at 794 .

13. See id. The defendant also alleged that Green had participated in a "lock-in," but his participation in the "lock-in" was not confirmed. See id. at 795 n.3.

14. See id. at 796.

15. See id.

16. See id. at 797.

17. See id. at 804. The prima facie case requirement in the disparate treatment context differs from the prima facie case requirement in some other legal contexts. Rather than consisting of evidence sufficient to prove all required elements of the plaintiff's claims, it simply requires the plaintiff to "eliminate[] the most common nondiscriminatory reasons for the plaintiff's rejection." Texas Dep't of Community Affairs v. Burdine, 450 U.S. 248, 254 (1981). As the Burdine Court stated:

The phrase "prima facie case" not only may denote the establishment of a legally mandatory, rebuttable presumption, but also may be used by courts to describe the plaintiff's burden of producing enough evidence to permit the trier of fact to infer the fact at issue. McDonnell Douglas should have made it apparent that in the Title VII context we use "prima facie case" in the former sense.

Id. at $254 \mathrm{nl} .7$ (citation omitted). 
(i) that he belongs to a racial minority; (ii) that he applied and was qualified for a job for which the employer was seeking applicants; (iii) that, despite his qualifications, he was rejected; and (iv) that, after his rejection, the position remained open and the employer continued to seek applicants from persons of [plaintiff's] qualifications. ${ }^{18}$

Next, the Court found that McDonnell Douglas had satisfied its burden by pointing to Green's participation in unlawful conduct against it as the cause for his rejection. 19 The Court then held that on remand Green "must be afforded a fair opportunity to show that petitioner's stated reason for respondent's rejection was in fact pretext." ${ }^{20}$

Although the McDonnell Douglas Court laid out a general burdenshifting frainework for cases in which the plaintiff relies on circumstantial evidence of discrimination, it did little to explain how future courts should apply that frainework. The Court did not explain, for example, whether the burden placed on the defendant to provide a legitimate nondiscriminatory reason for its decision was one of production or of persuasion. ${ }^{21}$ Further, it did not explain what it meant by the plaintiff's opportunity to show that the stated reason was "pretext." As Part II of this Comment will later illustrate, the Court's failure to explain its use of the term "pretext" has led to an overly narrow interpretation of the framework's application, one that erroneously equates the falsity-of-proffered-reason method of proof with the overarching McDonnell Douglas frainework.

lt was hardly surprising, therefore, given the McDonnell Douglas Court's want of explanation, that several years later the Court found it necessary to clarify the burdens of the parties and elaborate on the role of the fraunework in adjudicating Title VII claims. In Texas Department of Community Affairs v. Burdine, ${ }^{22}$ the plaintiff had been passed up for promotion and was subsequently terminated. ${ }^{23}$ She filed suit alleging that the decisions were based on gender discrimination in violation of Title VII. ${ }^{24}$ The Court of Appeals vacated the District Court's fiuding for the defendant, holding instead that the defendant had the burden of proviug the existence of a legitimate nondiscriminatory reason..$^{25}$

18. McDonnell Douglas, 411 U.S. at 802 . In a footnote, the Court specifically noted that the proof required to establish a prima facie case "is not necessarily applicable in every respect to differing factual situations." Id. at 802 n.13.

19. See id. at 803 .

20. Id. at 804 .

21. See infra note 27 and accompanying text (discussing these burdens of proof and the Court's subsequent resolution of the issue).

22. 450 U.S. 248 (1981).

23. See id. at 250-51.

24. See id at 251.

25. See id at 252. 
The Supreme Court reversed. ${ }^{26}$ It held that the burden shift from plaintiff to defendant upon establishment of the prima facie case is merely one of production, not of persuasion. ${ }^{27}$ Noting that the prima facie case "serves an important function in the litigation" because it "eliminates the most common nondiscriminatory reasons for the plaintiff's rejection," 28 the Court explained that the prima facie case creates a presumption of discrimination which the defendant must rebut, but that the plaintiff retains the "ultimate burden of persuading the court that she has been the victim of intentional discrimination." ${ }^{29}$ According to the Burdine Court, therefore, the defendant need only produce evidence of a nondiscriminatory reason, not persuade the jury that the proffered reason is the real reason for its decision.

With these two cases, McDonnell Douglas and Burdine, the Court established the basic structure under which a plaintiff can use circumstantial evidence to prove disparate treatment in violation of Title VII. This Comment proposes that within that framework lie the two currently existing inferential methods of proof-the falsity-of-proffered-reason method of proof and the motivating-factor method of proof. Under the former, the plaintiff can prove disparate treatment by showing that the defendant's proffered reason for its decision is false ${ }^{30}$ Under the latter, the plaintiff instead can prove disparate treatment by showing that the defendant's consideration of the plaintiff's race, color, religion, sex, or national origin was a motivating factor in the adverse decision. ${ }^{31}$

\section{The Falsity-of-Proffered-Reason Method of Proof}

According to the Burdine Court, one way in which the plaintiff can satisfy her burden of proving that she was the victim of intentional discrimination is "by showing that the employer's proffered explanation is unworthy of credence." reason" method of proof because through it the plaintiff proves that the defendant was motivated by impermissible factors by showing that the proffered reason for the decision is false..$^{33}$ A plaintiff cannot succeed using

26. See id.

27. See id. at 254-55 ('It is sufficient if the defendant's evidence raises a genuine issue of fact as to whether it discriminated against plaintiff.").

28. Id. at 253-54.

29. Id. at 256 .

30. See St. Mary's Honor Ctr. v. Hicks, 509 U.S. 502, 511 (1993).

31. See Civil Rights Act of 1991, Pub. L. No. 102-166, § 107, 105 Stat. 1075 (codified at 42 U.S.C. $\S \S 2000 \mathrm{e}-2(\mathrm{~m}), 2000 \mathrm{e}-5(\mathrm{~g})(2)(\mathrm{B})(1994))$. According to the House Report, discrimination is a motivating factor under section 107 when it "actually contributed or was otherwise a factor in an employment decision or action" H.R. REP. No. 102-40(I), at 48 (1991), reprinted in 1991 U.S.C.C.A.N. 549, 586.

32. Burdine, 450 U.S. at 256.

33. Courts often call this method the "pretext" method; to do so, however, is misleading because 
this method of proof without attacking the defendant's proffered reason and proving it false.

The falsity-of-proffered-reason method was called into question in a 1993 decision, St. Mary's Honor Center v. Hicks. ${ }^{34}$ Prior to the Court's grant of certiorari in Hicks, a three-way circuit split had developed. ${ }^{35}$ Some circuits held that if the plaintiff succeeded in proving that the reason proffered by the defendant was false, then judginent must be entered for the plaintiff. ${ }^{36}$ Other circuits held that the plaintiff must always present evidence of discriminatory intent in addition to proving the defendant's proffered reason false. ${ }^{37}$ Still other circuits permitted, but did not mandate, a finding for the plaintiff upon a showing of the falsity of the defendant's proffered reason. ${ }^{38}$

In Hicks, plaintiff Hicks was a black shift commander at St. Mary's Honor Center, a state halfway house. ${ }^{39}$ Hicks alleged that he had been discharged because of his race. ${ }^{40} \mathrm{St}$. Mary's responded that it had discliarged Hicks because he had accunnulated several serious rules violations. ${ }^{41}$ The District Court found that Hicks had established a prima facie case and, acting as trier of fact, that the nondiscriminatory reasons offered by St. Mary's were unworthy of belief. ${ }^{42}$ Nonetheless, it ruled in favor of St. Mary's, finding that Hicks had failed to prove that the decision was racially rather than personally motivated. ${ }^{43}$ The Court of Appeals reversed, holding that the fact finder's determination that the proffered reason was false mandated a finding for the plaintiff. ${ }^{44}$ The Supreme Court reversed and took the middle line, holding that while the prima facie case together with rejection of the employer's asserted reasons in some cases may be sufficient to support a finding for the plaintiff, it does not mandate such a finding. ${ }^{45}$

The Court's decision in Hicks has been severely criticized as restricting the plaintiff's ability to prove disparate treatment through the

\footnotetext{
it confuses the specific method of proof with the overarching McDonnell Douglas tripartite framework. See infra notes 59-60 and accompanying text. I therefore declime to use the term "pretext," and instead adopt the term "falsity-of-proffered-reason."

34. 509 U.S. 502 (1993).

35. See Deborah C. Malamud, The Last Minuet: Disparate Treatment After Hicks, 93 Mrch. L. Rev. 2229, $2234 \mathrm{n} .23$ (1995) (explaining the position of courts prior to Hicks).

36. See id.

37. See id.

38. See id.

39. See Hicks, 509 U.S. at 504.

40. See id. at 505 .

41. See id. at 507.

42. See id. at 507-08.

43. See id.

44. See id. at 508-09.

45. See id. at 511 .
} 
falsity-of-proffered-reason method of proof. ${ }^{46}$ Prior to Hicks many courts and commentators believed a plaintiff's success in showing the defendant's proffered reason false resulted in a mandatory inference of intentional discrimination; after Hicks they found that the same showing of falsity would not always be enough. Despite the outcry after the decision, however, Hicks has also engendered some grudging support. ${ }^{47}$ Moreover, regardless of the outcome of the Hicks debate, the falsity-of-proffered-reason method of proof remains one available method of proof for a plaintiff alleging intentional discrimination in violation of Title VII.

\section{The Motivating-Factor Method of Proof}

The Supreme Court first articulated what is now known as the "inotivating-factor" method of proof in a 1989 decision, Price Waterhouse v. Hopkins. ${ }^{48}$ There, a plurality of the Court articulated what it termed the "mixed-motive" model of proof. ${ }^{49}$ In Price Waterhouse, the plaintiff, a woman named Ann Hopkins, had been refused partnership at a major accounting firm. ${ }^{50}$ She sued for discrimination on the basis of sex in violation of Title VII. ${ }^{51}$ The evidence showed that Hopkins had received several negative performance evaluations, some of which commented on her abrasive personality and difficult relations with staff members. ${ }^{52}$ The evidence also indicated, however, that some of the negative evaluations were based on impermissible gender stereotypes, including suggestions that Hopkins "overcoinpensated for being a woman," that she should "walk more

46. See, e.g., Deborah A. Calloway, St. Mary's Honor Center v. Hicks: Questioning the Basic Assumption, 26 CoNN. L. REv. 997 (1994) (calling for congressional action to overrule Hicks); Melissa A. Essary, The Dismantling of McDonnell Douglas v. Green: The High Court Muddies the Evidentiary Waters in Circumstantial Discrimination Cases, 21 PEPP. L. REv. 385 (1994) (evaluating the impact of Hicks on plaintiffs' Title VII disparate treatment claims); Shannon R. Joseph, Note, Employment Discrimination: Shouldering the Burden of Proof After St. Mary's Honor Center v. Hicks, 29 WAKE FOREST L. REv. 963, 995 (1994) (stating that Hicks manifests the Court's willingness "to twist the words of its prior decisions in order to extract a result that subverts the intended result of civil rights legislation").

47. See Malamud, supra note 35, at 2244-54 (arguing that the Supreme Court had failed to set the prima facie case threshold high enough to mandate a judgment for the plaintiff in all cases in which the jury disbelieves the employer's proffered reason, but in which the plaintiff only proffercd evidence establishing the prima facie case).

48. 490 U.S. 228 (1989).

49. A note on terminology: The plurality in Price Waterhouse called its method of proof the "mixed-motive" method. See id. at 247 n.12. Technically, the Civil Rights Act of 1991 overruled the "mixed-motive" method of Price Waterhouse and replaced it with what is called the "motivatingfactor" method. See infra notes 72-74 and accompanying text. For the most part, however, the analysis presented here does not turn on the particulars of the two methods. Accordingly, I use the term "mixedmotive" to refer to the specific Price Waterhouse articulation of the method and use the term "motivating-factor" to refer both to the current post-1991 Act method as well as to a generic motivating-factor method that encompasses both the Price Waterhouse method and the current method.

50. See Price Waterhouse, 490 U.S. at 231-33.

51. See id. at 231-32.

52. See id. at 234. 
femininely, talk more femininely, dress more femininely, wear make-up, have her hair styled, and wear jewelry," or that she should take "a course at charm school.",s3

On these facts, Hopkins would have been unlikely to prevail under the falsity-of-proffered-reason method of proof discussed above; she could not have shown that the reason proffered by Price Waterhouse, namely failure to promote based on negative performance evaluations, was false. Instead of analyzing her case under the falsity-of-proffered-reason method of proof, however, the district court, court of appeals, and the Supreme Court each applied some variation of a method of proof under which Hopkins could prove discrimination so long as she proved that the decision was motivated in part by the impermissible gender stereotypes. ${ }^{54}$

The district court concluded that Price Waterhouse had discriminated against Hopkins on the basis of sex by allowing sex stereotyping to play a role in the decision. However, the court also held that Price Waterhouse could avoid equitable relief by proving by clear and convincing evidence that it would have made the same decision even absent the discrimination..$^{55}$ The court of appeals affirmed, but held that even if a plaintiff proves that discrimination played a role in the decision, the defendant will not be found liable if it can show, by clear and convincing evidence, that it would have made the same decision absent the impermissible motive. ${ }^{56}$ The Supreme Court, in its plurality opinion in Price Waterhouse, adopted neither the district court's nor the court of appeals' analysis. Instead, it held that when a plaintiff in a Title VII case "proves that her gender played a motivating part in an employment decision, the defendant may avoid a finding of liability only by proving by a preponderance of the evidence that it would have made the same decision even if it had not taken the plaintiff's gender into account.".57

The importance of the Price Waterhouse decision, however, lies not in its articulation of the details of the method of proof, for the Civil Rights Act of 1991 subsequently overruled that part of the decision. ${ }^{58}$ Rather, the importance of the decision lies in when the inethod of proof applies. The Supreme Court in Price Waterhouse insisted on distinguishing its "mixedmotive" method of proof from what it called the "pretext" model used in

53. Id. at 235.

54. See id. at 236-37 (discussing lower court decisions); Hopkins v. Price Waterhouse, 825 F.2d 458, 470-71 (D.C. Cir. 1987); Hopkins v. Price Waterhouse, 618 F. Supp. 1109, 1120 (D.D.C. 1985).

55. See Price Waterhouse, 490 U.S. at 236-37; Hopkins, 618 F. Supp. at 1120.

56. See Price Waterhouse, 490 U.S. at 237; Hopkins, 825 F.2d at 471-72.

57. Price Waterhouse, 490 U.S. at 258.

58. See Civil Rights Act of 1991, Pub. L. No. 102-166, § 107, 105 Stat. 1075 (codified at 42 U.S.C. $\$ \S 2000 \mathrm{e}-2(\mathrm{~m}), 2000 \mathrm{e}-5(\mathrm{~g})(2)(B)(1994))$. See infra Section I.B for discussion of the Act and its effect.

59. See infra Part II for an argument that the Price Waterhouse Court erroneously perceived the McDonnell Douglas framework and the falsity-of-proffered-reason method of proof as one and the 
McDonnell Douglas. ${ }^{60}$ As Part II of this Comment will later address, the Court's confusion and lack of clarity in this regard has led to devastating misinterpretation of the disparate treatment framework.

In distinguishing its "mixed-motive" method of proof from that in the "pretext" model, the plurality in Price Waterhouse focused on whether the defendant's decision involved mixed motives or a single motive. As the plurality opimion put it, the key distinction is whether the "decision was the product of a mixture of legitimate and illegitinate motives."61 Justice O'Connor in her concurrence, on the other hand, focused on the type of evidence presented by the plaintiff. She required a plaintiff to present "direct evidence that decisionmakers placed substantial negative reliance on an illegitmate criterion in reaching their decision" as a threshold requirement to use the "mixed-inotives" method of proof. ${ }^{62}$ The dissent, authored by Justice Kennedy, also einphasized the term "direct" and characterized the plurality opinion as requiring "direct and substantial evidence of discriminatory animus" in order for the Price Waterhouse method of proof to apply. ${ }^{63}$

Lower court interpretations of the Price Waterhouse decision seized upon Justice O'Connor's, as well as the dissent's, reference to "direct" evidence. Six circuits interpreted Price Waterhouse as establishing a "direct evidence" threshold for access to the "mixed-inotive" method of proof. ${ }^{64}$ These cases generally required a plaintiff to produce direct evidence of discriminatory intent in order to receive a motivating-factor analysis. ${ }^{65}$ Although these courts consistently imposed a requirement of "direct evidence," they provided no consistent definition of the term, and often allowed a motivating-factor analysis in cases in which no direct evidence had really been presented. ${ }^{66}$ Further, three circuits permitted a motivating-factor method of proof in cases in which the plaintiff presented circumstantial evidence, but only if that evidence was "directly tied to" or

same and labeled it the "pretext" model.

60. See Price Waterhouse, 490 U.S. at 247 n.12.

61. Id. at 247 .

62. Id. at 277 (O'Connor, J., concurring). For a discussion of Justice O'Connor's dircet evidence requirement, see infra notes $128-135$ and accompanying text.

63. Price Waterhouse, 490 U.S. at 280 (Kennedy, J., dissenting).

64. The First, Fifth, Sixth, Seventh, Tenth, and Eleventh Circuits required "direct" evidence for the Price Waterhouse method of proof. See Michael A. Zubrensky, Note, Despite the Smoke, There is No Gun: Direct Evidence Requirements in Mixed-Motives Employment Law After Price Waterhouse v. Hopkins, 46 STAN. L. REv. 959, 973-75 (1994); see also Linda H. Krieger, The Content of Our Categories: A Cognitive Bias Approach to Discrimination and Equal Employment Opportunity, 47 STAN. L. REv. 1161, 1220 (1995) (citing to many of the same cases, but finding the Seventh Circuit in intra-circuit conflict).

65. See Krieger, supra note 64 , at 1220 ; Zubrensky, supra note 64 , at $973-75$.

66. See Krieger, supra note 64, at 1221 (discussing the Fifth Circuit's use of the direct evidence requirement). 
"directly reflecting" the alleged discrimination. ${ }^{67}$ Only the Fourth Circuit imposed no evidence-based restrictions on the plaintiff's use of a motivating-factor method of proof. ${ }^{68}$

\section{B. The Civil Rights Act of 1991}

\section{Changes Instituted by the Act}

The Civil Rights Act of $1991^{69}$ made several important changes to existing disparate treatment jurisprudence. First, it authorized damages, both consequential and punitive, in disparate treatment cases. ${ }^{70}$ Second, while prior to the Act a judge decided disparate treatment claims, pursuant to the 1991 Act, a jury may decide those claims for which the plaintiff requests damages. ${ }^{71}$ Finally, section 107 of the Act overruled Price Waterhouse im part, amending Title VII by adding sections $703(\mathrm{~m})$ and $706(\mathrm{~g})(2)(\mathrm{B}){ }^{72}$

Section 703(m) of Title VII reads:

Except as otherwise provided in this subchapter, an unlawful employment practice is established when the complaining party demonstrates that race, color, religion, sex, or national origin was a motivating factor for any employment practice, even though other factors also motivated the practice. ${ }^{73}$

Section $706(\mathrm{~g})(2)(B)$ of Title VII reads:

On a claim in which an mdividual proves a violation under section 703(m) of this title and a respondent demonstrates that the respondent would have taken the same action $m$ the absence of the impermissible motivating factor, the court-

(i) may grant declaratory relief, injunctive relief (except as provided in clause (ii)), and attorneys' fees and costs demonstrated to be directly attributable only to the pursuit of a claim under section 2000e-2(in) of this title; and

(ii) shall not award dainages or issue an order requiring any admission, reinstatement, hiring, promotion, or payment, described in subparagraph (A). ${ }^{74}$

According to the provisions, therefore, under section $703(\mathrm{~m})$ of Title VII the defendant will be liable if the plaintiff can prove that his protected

67. See Krieger, supra note 64, at 1220; Zubrensky, supra note 64, at 976.

68. See supra note 64 .

69. Pub. L. No. 102-166, 105 Stat. 1071 (1991) (codified in scattered sections of 42 U.S.C).

70. See Civil Rights Act of 1991, Pub. L. No. 102-166, $\S 102,105$ Stat. 1072 (codified at 42 U.S.C. $\S 1981 \mathrm{a}(\mathrm{a})(1994))$.

71. See id. $\$ 1981 \mathrm{a}(\mathrm{c})$.

72. See Civil Rights Act of 1991, Pub. L. No. 102-166, § 107, 105 Stat. 1075 (codified at 42 U.S.C. $\$ \$ 2000 \mathrm{e}-2(\mathrm{~m}), 2000 \mathrm{e}-5(\mathrm{~g})(2)(B)(1994))$.

73. Civil Rights Act of $1991 \S 703(\mathrm{~m}), 42$ U.S.C. $\$ 2000 \mathrm{e}-2(\mathrm{~m})$. The legislative history of the Act reveals that it was intended to overrule the Price Waterhouse plurality's articulation of the method. See H.R. REP. No. 102-40(I), at 45 (1991), reprinted in 1991 U.S.C.C.A.N. 549, 585.

74. 42 U.S.C. $\& 2000 \mathrm{e}-5(\mathrm{~g})(2)(B)(1994)$. 
group status played a motivating part in the decision. Then, under section $706(\mathrm{~g})(2)(\mathrm{B})$, if the defendant can prove by a preponderance of the evidence that it would have made the same decision absent the impermissible factor, the plaintiff's remedy will be limited to declaratory or injunctive relief and attorneys' fees and costs. The method instituted by the 1991 Act is more favorable to plaintiffs than the Price Waterhouse "mixed-motive" method because it allows a plaintiff to prevail even if the defendant can prove that it would have made the same decision anyway. In other words, the Act makes clear that in order to prevail a plaintiff need not prove that the employer's reliance on an impermissible factors was the "but for" cause of the adverse decision.

Although it was clear that the 1991 Act overruled the Price Waterhouse formulation of the "mixed-motive" method of proof and replaced that method with the "motivating factor" method, it was not clear whether the Act also affected the method's availability. Just when section 107 of the 1991 Act applies, and thus the motivating-factor method is available to plaintiffs, has been the subject of considerable confusion and debate.

\section{Interpretation of the 1991 Act}

The Supreme Court has yet to address the question of whether section 107 of the 1991 Act applies to all individual disparate treatment claims under Title VII or only to those in which the plaintiff presents "direct" evidence, as Justice O'Connor required in Price Waterhouse. The Court's only statement on the issue appeared in dicta in Landgraf v. USI Film Products, ${ }^{75}$ a case considering the Act's retroactivity. There the Court stated that section 107 "responds to Price Waterhouse . . by setting forth standards applicable im 'mixed-motive' cases."76

The Fourth Circuit has since relied on this statement as evidence that the Court intended to restrict the application of section 107 to those cases in which the plaintiff has presented direct evidence of discrimination. ${ }^{7}$ This conclusion, however, is unfounded. Not only was the statement made in dicta, but it fails to reveal any indication that the Court (not to mention Congress) finds "mixed motive" synonymous with "direct evidence."

The Court in Landgraf, while failing to clarify the applicability of the section 107 method of proof, did affect interpretation of the Act by holding that the Act applies only to events arising after its effective date. ${ }^{78}$ This, together with lengthy administrative procedures, has slowed lower court

75. 511 U.S. 244 (1994).

76. Id. at 251 .

77. See Fuller v. Phipps, 67 F.3d 1137, 1143 (4th Cir. 1995) (retaining a "direct evidence" requirement and stating that the Supreme Court "has indicated as much").

78. See Landgraf, 511 U.S. at 286 (holding right to trial by jury does not apply to Title VII cases pending on appeal at the time of Act's enactment). 
interpretation of the Act. Only within the last few years have circuits begun applying Title VII as amended by the 1991 Act.

Current circuit interpretation of the Act is far from consistent. ${ }^{79}$ To date, five circuits have yet to reveal their interpretation of the scope of section $107 .{ }^{80}$ Of the other six circuits, three, the First, Fourth, and Eighth, appear to have decided that the 1991 Act merely modified the method of proof described in Price Waterhouse without altering the applicability of the inethod. According to these circuits, therefore, a "direct" evidence requirement as articulated by Justice O'Connor in her concurrence in Price Waterhouse determines when section 107 will apply. ${ }^{81}$ In contrast, the Second, Seventh, and Eleventh circuits appear to have decided that the 1991 Act's motivating-factor method can be used without regard to the type of evidence presented. ${ }^{82}$ Further, while perhaps not yet adopting such

79. Because the inconsistency stems from a struggle to divine a coherent framework rather than from a principled disagreement over the direction of disparate treatment jurisprudence, thorough analysis on the part of courts is often lacking, and categorization accordingly difficult. See, e.g., Fuller, 67 F.3d at 1142-44 (interpreting the 1991 Act to require "direct" evidence for motivating-factor method of proof, without mention of an earlier Fourth Circuit decision, White v. Federal Express Corp., 939 F.2d 157, 169 (4th Cir. 1991), which indicated there was go direct evidence requirement for the "mixed-motives" method).

80. The Third, Fifth, Sixth, Ninth, and Tenth Circuits have not clearly ruled on the issue, despite frequent decisions involving claims of disparate treatment. The Ninth Circuit, for example, has developed an intricate framework at the summary judgment stage, without mention of the 1991 Act's motivating-factor method of proof. See, e.g., Godwin v. Hunt Wesson, Inc., 150 F.3d 1217 (9th Cir. 1998) (applying Title VII jurisprudence to claim under California Fair Employment and Housing Act without mention of 1991 Act or motivating-factor method of proof).

81. See Day v. Johnson, 119 F.3d 650, 654 (8th Cir. 1997) (reversing jury verdict on grounds that plaintiff did not show falsity of proffered reason and establish discrimination as sole cause, stating that "because [plaintiffs] produced no direct evidence of discriminatory intent, we must decide whether they introduced sufficient circumstantial evidence to permit the district court reasonably to infer that [defendant's] expressed reasons were unworthy of belief'), cert. denied sub nom., Hollowell v. Johnson, 118 S. Ct. 707 (1998); Smith v. F.M. Morse \& Co., 76 F.3d 413, 419 n.3 (1st Cir. 1996) (stating in dicta that "the Price Waterhouse framework for proof of 'mixed motive' discrimination ... is somewhat different under the 1991 Act") (citing Fuller v. Phipps, 67 F.3d 1137, 1142 (4th Cir. 1995)); Fuller v. Phipps, 67 F.3d 1137, 1142 (4th Cir. 1995) (interpreting the 1991 Act as allowing use of the motivating-factor method of proof only when the plaintiff has presented "direct evidence that decisionmakers placed substantial negative reliance on an illegitimate criterion"') (quoting Price Waterhouse v. Hopkins, 490 U.S. 228, 277 (1989) (O'Connor, J., concurring)).

82. See Fields v. New York State Office of Mental Retardation and Developmental Disabilities, 115 F.3d 116, 122 (2d Cir. 1997) (interpreting the 1991 Act as amending Title VII so that a motivatingfactor instruction is available to all plaintiffs but limiting the "same decision" instruction of section $706(\mathrm{~g})(2)$ upon request of the plaintiff to those cases in which there is direct evidence or circumstantial evidence that is "tied directly to the alleged discriminatory animus") (quoting Ostrowski v. Atlantic Mutual Ins. Cos., 968 F.2d 171, 182 (2d Cir. 1992)); Harris v. Shelby County Bd. of Educ., 99 F.3d 1078 (11th Cir. 1996) (applying section 703(m) and section 706(g)(2) to case based on circumstantial evidence, granting summary judgment in favor of the defendant on affirmative defense, section $706(\mathrm{~g})(2)$, but remanding for determination of liability under section 703(m)); Hennessy v. Penril Datacomm Networks, Inc., 69 F.3d 1344, 1351 (7th Cir. 1995) (affirming district court's "motivating factor" section 703(m) charge to the jury because the plamtiff's case was based on "direct" evidence, but finding that even if the plaintiff had proceeded under the indirect inodel, the ultimate question for the jury would be "whether Ms. Hennessy's sex was a motivating factor in Penril's decision to fire 
a view in practice, ${ }^{83}$ the Eighth Circuit has promulgated model jury instructions that interpret the 1991 Act as "expressly mandating a motivating factor/same decision analytical format" for disparate treatment Title VII cases. ${ }^{84}$ The jury instructions therefore provide for a motivating factor/same decision instruction without reference to a direct evidence requirement, but in doing so do away with the falsity-of-proffered-reason method of proof altogether. ${ }^{85}$

These differing interpretations of the 1991 Act's effect on individual disparate treatment jurisprudence illustrate the need for clarification about the appropriate framework and its relationship to the methods of proof. This Comment offers such clarification. Focusing on the McDonnell Douglas tripartite framework as it relates to the two recognized inferential inethods of proof, Part II argues that section 107 of the 1991 Act defines an alternate method of proof to the falsity-of-proffered reason method of proof. Further, Part II illustrates that continued reliance on a "direct evidence" requirement for application of section 107 is not only unnecessary but detrimental to coherent and consistent adjudication of disparate treatment claims under Title VII.

II

Two Methods of Proof Within the Overarching McDonnell Douglas FrAMEWORK

This Comment proposes that the falsity-of-proffered-reason method of proof and the motivating-factor method of proof coexist within the McDonnell Douglas framework, and are available regardless of the type of evidence presented by a plaintiff. This Part argues that the proposal presented here is supported by existing case law as well as the 1991 Act and, inoreover, that it makes practical sense. In doing so, the Part reveals that the Court's decisions regarding the McDonnell Douglas framework and available methods of proof as well as Congress's 1991 amendments to Title VII have been misinterpreted, and that those misinterpretations have had disastrous consequences for disparate treatment jurisprudence. The

her").

83. See Day v. Johnson, 119 F.3d 650, 654 (8th Cir. 1997) (stating that because the plaintiffs had not presented direct evidence of discrimination, the proper analysis required a showing that the defendant's proffered reason was unworthy of belief). But see Kelley E. Dowd, Casenote,The Correct Application of the Evidentiary Standard in Title VII Mixed-Motive Cases: Stacks v. Southwestern Bell Yellow Pages, Inc., 28 CREIGHTON L. REv. 1095 (1995) (interpreting pre-Act case as allowing the Price Waterhouse motivating-factor analysis on a showing of either direct or circumstantial evidence).

84. Manual of Model Civil Jury Instructions for the District Courts of the Eighth Circuit $\$ 5$, at 850 (1992).

85. See id. $\S \S 5.01,5.01 \mathrm{~A} \&$ committee cmts., at 8-53 (stating that "the plaintiff prevails on the issue of liability if he or she shows that discrimination was a 'motivating factor' in the challenged employment decision"). For further discussion of the Eighth Circuit's model jury instructions, see infra Section II.C. 
proposed relationship between the McDonnell Douglas framework and two existing methods of proof presents a workable solution to the chaos.

\section{A. Existing Case Law and the Proposal}

The proposal presented here rests on two interrelated premises: (1) that the McDonnell Douglas framework encompasses both the falsity-ofproffered-reason method of proof and the motivating-factor method of proof; and (2) that whether the plaintiff presents direct evidence or circumstantial evidence is relevant only in determining whether the McDonnell Douglas framework is necessary at all and not in distinguishing between the two methods of proof. Each of these premises finds support in the case law, but, due in large part to lack of clarity on the part of the Supreme Court, has been misinterpreted by many lower courts.

\section{The McDonnell Douglas Framework Encompasses Both Methods of Proof}

The McDonnell Douglas framework as explained by the Supreme Court never eliminated a plaintiff's option to prove disparate treatment through circumstantial evidence without attacking the defendant's proffered reason. Rather, in McDonnell Douglas and Burdine the Court laid out an overarching, tripartite framework for claims relymg on circumstantial evidence and offered plaintiffs the option of proving disparate treatment through an attack on the defendant's proffered reason. Two methods of proof continued to exist within the McDonnell Douglas framework, and the Hicks and Price Waterhouse Courts simply modified those methods.

\section{a. McDonnell Douglas and Burdine-Recognizing Two Methods of Proof}

Circumstances leading up to McDonnell Douglas, together with the underlying rationale of the McDonnell Douglas framework as explamed by the Court, poimt to the existence of an overarching framework that encompasses two alternate inethods of proof. Prior to McDonnell Douglas, individual disparate treatment claims under Title VII were tried using the general civil inethod: In order to prevail, a plaintiff was required to prove by a preponderance of the evidence that he was the victim of intentional discrimination. ${ }^{86}$ In theory, this could be done with direct or circumstantial evidence. ${ }^{87}$ In practice, while cases in the late ' 60 s and early ' 70 s often

86. See Frockt v. Olin Corp., 344 F. Supp. 369, 370 (S.D. Ind. 1972) (stating that "the plaintiff has the burden of showing by a preponderance of evidence that [her] employer has intentionally discriminated against her on [the basis of a protected factor]"); Andres v. Southwestern Pipe, Inc., 321 F. Supp. 895, 898 (W.D. La. 1971) ("The burden is upon the plaintiff to show that his employer intentionally discriminated against him on account of his race."), aff'd, 446 F.2d 899 (5th Cir. 1971). Although the plaintiff must prove intentional discrimination, the requisite intent need not amount to specific intent. See Andres, 321 F. Supp. at 898.

87. See Frockt, 344 F. Supp. at 369-72; Andres, 321 F. Supp. at $896-900$ (both plaintiffs relying 
involved either facially discriminatory policies or otherwise "smoking gun" evidence, these types of direct evidence became more scarce as employers became savvy with respect to Title VII. ${ }^{88}$ Without such direct evidence, plaintiffs using the general civil method had difficulty proving discrimination. ${ }^{89}$

In response to this difficulty, the Court established a framework for disparate treatment claims based on circumstantial evidence. ${ }^{90}$ The Court in McDonnell Douglas neglected to state the rationale behind its decision to adopt the tripartite framework, but the rationale as explained in several subsequent decisions supports this interpretation. In Burdine, the Court stated that the McDonnell Douglas framework "serves to bring the litigants and the court expeditiously and fairly to th[e] ultimate question [of whether the plaimtiff has been the victim of imtentional discrimination]." to explain that the requirement of a prima facie showing serves to "eliminat[e] the most common nondiscriminatory reasons for the plaintiff's rejection." Similarly, in International Brotherhood of Teamsters, the Court explaimed:
Although the McDonnell Douglas formula does not require direct proof of discrimination, it does demand that the alleged discriminatee demonstrate at least that his rejection did not result from the two most common legitimate reasons on which an employer might rely to reject a job applicant: an absolute or relative lack of qualifications or the absence of a vacancy in the job sought. $^{93}$

The prima facie showing requirement thus assists defendants by forcing the plaintiff to eliminate the most common nondiscriminatory reasons before going forward with the suit. In addition, the prima facie showing assists plaintiffs by creating a presumption of discrimination. As the Court stated in Furnco Construction Corp. v. Waters, the prima facie showing is "proof

on circumstantial evidence).

88. See Troupe v. May Dep't Stores Co., 20 F.3d 734, 736 (7th Cir. 1994) ("[E]mployers have taught their supervisory employees not to put discriminatory beliefs or attitudes into words, oral or written."); John J. Donohue III \& Peter Siegelman, The Changing Nature of Employment Discrimination Litigation, 43 STAN. L. REv. 983, 1032 (1991) (analyzing causes and consequences of major changes in federal employment discrimination litigation and finding, among other things, that "the flagrant and obvious violations of the pre-Title VII era-systematic refusal to hire women or minorities for certain jobs, gross disparities in pay for identical jobs, segregated work facilities-were much more likely to produce plaintiff victories than the subtler and less-frequent forms of discrimination practiced today").

89. See Frockt, 344 F. Supp. at 369 (plaintiff relying on circumstantial evidence and court finding no discrimination); Andres, $321 \mathrm{~F}$. Supp. at 895 (same).

90. See supra Section II.B for further discussion of $M c$ Donnell Douglas framework as applying only to claims for which plaintiff relies on circumstantial evidence.

91. Texas Dep't of Community Affairs v. Burdine, 450 U.S. 248, 253 (1981).

92. Id, at 253 .

93. International Brotherhood of Teamsters v. United States, 431 U.S. 324, 358 n.44 (1977). 
of actions taken by the employer from which we infer discriminatory animus because experience has proved that in the absence of any other explanation, it is more likely than not that those actions were bottomed on impermissible considerations." 94 This presumption of discrimination triggered by the prima facie case effectively compels the defendant to come forward with an explanation for the decision, giving the plaintiff some indication of the employer's reasoning where information may otherwise be difficult to obtain.

The McDonnell Douglas framework therefore works to advance the factual inquiry "to a new level of specificity" and to "frame the factual issue with sufficient clarity," lishes the ultimate requisite inference of discrimination by showing that the defendant's proffered reason is false or, under the general civil method, by showing that the defendant was more likely motivated by an impermissible factor. Accordingly, the Court's rationale behind the McDonnell Douglas framework neither requires, nor implies, that the falsity-of-profferedreason method of proof is the sole inethod of proof within the framework.

The McDonnell Douglas opmion itself provides further support for the proposed framework. Although the McDonnell Douglas Court gave little guidance or explanation when it promulgated the tripartite framework, what guidance it did provide lends support to a framework with two possible methods of proof. After laying out the three stages of the framework, the Court listed several examples of evidence relevant at the final stage. According to the Court, especially relevant to a showing that a defendant's stated reason for an employee's rejection was in fact pretext would be "evidence that white employees involved in acts against petitioner of comparable seriousness to the 'stall-in' were nevertheless retained or rehired." "Furthermore, the Court noted, "[o]ther evidence that may be relevant to any showing of pretext includes facts as to the petitioner's treatment of [plaintiff] during his prior term of employment; [defendant's] reaction, if any to [plaintiff's] legitimate civil rights activities; and [defendant's] general policy and practice with respect to minority employment. .97

These examples of relevant evidence enumerated by the Court support a reading of the final stage of the McDonnell Douglas framework as involving two methods of proof, one that flows through the defendant's proffered reason and one that does not. The first example of relevant evidence goes specifically to the falsity of the proffered reason in that, had the defendant not proffered the reason, the fact that the white employees

94. Furnco Constr. Corp. v. Waters, 438 U.S. 567, 579-80 (1978).

95. Burdine, 450 U.S. at 255.

96. McDonnell Douglas Corp. v. Green, 411 U.S. 792, 804 (1973).

97. Id. at 804-05. 
participated in comparable activities would be irrelevant. The third example might also be seen as going to the falsity of the proffered reason in that, had the defendant not offered the plaintiff's illegal civil rights activity as the reason for his decision, evidence of his reaction to the plaintiff's legitimate civil rights activity would have little probative value. ${ }^{98}$ The other two examples do not involve, however, the falsity of the reason per se, but rather go "directly" to proving that the einployer's decision was motivated by race.

The Court's explanation of the framework in Burdine also supports this reading of the evidentiary examples in McDonnell Douglas. In holding that the plaintiff retains the burden of persuasion, the Court explained the final stage of the McDonnell Douglas tripartite framework:

[The plaintiff] now inust have the opportunity to demonstrate that the proffered reason was not the true reason for the employnient decision. This burden now merges with the ultimate burden of persuading the court that she has been the victim of iutentional discrinination. She may succeed in this either directly by persuading the court that a discriminatory reason inore likely motivated the employer or indirectly by showing that the employer's proffered explanation is unworthy of credence..$^{99}$

By citing the examples given by the McDonnell Douglas Court and explaining them in terms of proof "indirectly" through the proffered reason or "directly" without going through the proffered reason, the Burdine Court established that two equally and simultaneously available nethods of proof did in fact exist within the McDonnell Douglas frainework. ${ }^{100}$ According to this understanding of the frainework, therefore, the plaintiff did not need to prove that the proffered reason was "unworthy of credence" if she could show that her protected group status more likely motivated the decision.

The Burdine Court might be seen to have modified the general civil method for cases under the McDonnell Douglas framework with its

98. This evidence must bear on the plaintiff's race-based claim, for although the plaintiff in McDonnell Douglas did also allege discrimination in retaliation for his civil rights activities, that claim was dismissed by the trial court and not raised on appeal. See McDonnell Douglas v. Green, 411 U.S. $792,797 \&$ n.6 (1973). The chain of relevance here would presumably be that if the defendant had reacted in the same way to the plaintiff's legal civil rights activity as he did to the plaintiff's illegal civil rights activity, then the defendant was not distinguishing between the two on the basis of the activity, and the proffered explanation that he refused to hire the plaintiff on the basis of participation in illegal activity is false.

99. Burdine, 450 U.S. at 256 (citing McDonnell Douglas, 411 U.S. at 804-05).

100. The Court's use of the terms "indirect" and "direct" here may have led to some of the confusion surrounding the applicabihty of the motivating-factor method of proof. Although the Court's use of the terms here is relatively straightforward, the terms are not used in their evidentiary sense in that the presence of an inference is irrelevant. As a result, future courts, in an attempt to clarify the confusion instigated by Price Waterhouse, may have misinterpreted the use of the terms here as being evidentiary rather than rooted in common sense. See supra Section I.B.2. 
explanation that a plaintiff may demonstrate pretext by proving that her protected group status "more likely motivated the employer." ${ }^{01}$ Notwithstanding any intended modification by the Burdine Court, however, this second method of proof was further modified by the Court in Price Waterhouse. Upon enactment of the 1991 Civil Rights Act, it was modified still further by the addition of section 703(m), which places liability on the employer in cases in which the plaintiff can prove that her group status "was a motivating factor" in the employment decision. ${ }^{102}$

\section{b. Hicks-Blurring, but Not Erasing, the Line Between the Two Methods of Proof}

Both the holding and the reasoning of the Court's decision in St. Mary's Honor Center v. Hicks are consistent with a disparate treatment framework that includes the motivating-factor and the falsity-of-profferedreason methods of proof. The Hicks Court considered only the falsity-ofproffered-reason method of proof, deciding that falsity alone is not always enough to support a mandatory inference of intentional discrimination. ${ }^{103}$ This holding raises the burden of proof for plaintiffs proving intentional discrimination through the defendant's proffered reason; it does not, however, foreclose a plaintiff from proving his claim through the motivatingfactor method of proof. ${ }^{104}$

Similarly, the Hicks Court's discussion of the McDonnell Douglas framework reveals no imtention to limit the motivating-factor method of proof. By holding that the falsity-of-proffered-reason method requires something more than proving the defendant's proffered reason to be false, the Court in Hicks was squarely presented with its prior statement in McDonnell Douglas that a plaimtiff may succeed in showing pretext "either directly by persuading the court that a discriminatory reason more likely motivated the employer or indirectly by showing that the employer's proffered explanation is unworthy of credence."10s The Hicks Court disposed of the McDonnell Douglas statement by calling it "an inadvertence"106 to the extent "that it describes disproof of the defendant's reason as a totally independent, rather than an auxiliary, means of proving unlawful intent." ${ }^{107}$ This reasoning that the falsity-of-proffered-reason method of proof is an auxiliary rather than an independent means of

101. Burdine, 450 U.S. at 256 .

102. 42 U.S.C. $\$ 2000 \mathrm{e}-2(\mathrm{~m})$ (1994).

103. See St. Mary's Honor Ctr. v. Hicks, 509 U.S. 502, 511 (1993).

104. Note that the facts underlying the claim in Hicks predated the 1991 Act. See id at 504-05. Therefore, the second method was applied as it would be under Price Waterhouse. See supra note 78 and accompanying text.

105. Hicks, 509 U.S. at 517.

106. Id. at 518

107. Id. (emphasis added). 
proving intentional discrimination blurs the line between the two methods of proof, but it does not do away with the distinction altogether. For even if the plaintiff inust in some cases offer evidence of an employer's reliance on an mipermissible factor in addition to showing that the employer's proffered reason is false, the inference of discrimination will stein primarily from the proffered reason. The fact finder will infer unlawful discrimination from proof that the reason offered by the defendant for its decision is unworthy of belief and a cover-up for discrimination. Accordingly, an inference under the Hicks method of proof stems froin the proffered reason while an inference under the motivating-factor inethod does not.

\section{c. Price Waterhouse-Groundwork for Confusion}

Finally, the plurality opinion in Price Waterhouse is also consistent with the proposal presented here. This is true despite the fact that its explanation of the McDonnell Douglas framework led to unnecessary confusion and ultimately undermined the efficacy of its "mixed-notive," or inotivating-factor, method of proof. ${ }^{108}$ The plurality correctly saw the falsity-ofproffered-reason method as distinct from the motivating-factor method, and required direct evidence for neither. ${ }^{109}$ Further, it recognized that both the falsity-of-proffered-reason method and the motivating-factor inethod were available to the same plaintiff, and if the plaintiff could not prove her case through one, she may resort to the other. ${ }^{110}$

Lower court confusion surrounding the applicability of the Price Waterhouse analysis likely stemmed, however, from the plurality's limited view of the scope of the McDonnell Douglas frainework. The plurality equated the McDonnell Douglas frainework with the falsity-of-profferedreason method of proof. ${ }^{111}$ By doing so, it left no room within the McDonnell Douglas framework for a motivating-factor analysis. A motivating-factor analysis as explained by the plurality-and now as mandated by Title VII section 703(m)-does not require the plaintiff to prove that no legitimate factors played a part in the decision. In contrast, the

108. For purposes of this discussion, the differences between the Price Waterhouse "mixedmotive" method and the current "motivating-factor" method are unimportant. I therefore use the term "motivating-factor" here to include both methods.

109. See Price Waterhouse v. Hopkins, 490 U.S. 228, 240 n.6 (1989) (distinguishing Price Waterhouse from McDonald v. Santa Fe Trail Transportation Co., 427 U.S. 273 (1976), on grounds that $M c D o n a l d$ "dealt with the question whether the employer's stated reason for its decision was the reason for its action; unlike the case before us today, therefore, McDonald did not involve mixcd motives.").

110. In Price Waterhouse, the plurality statcd, "[I]ndeed, we expect that plaintiffs often will allege, in the alternative, that thcir cases are both.... If the plaintiff fails to satisfy the factfinder that it is more likely than not that a forbidden characteristic played a part in the employment decision, then she may prevail only if she proves ... that the employer's stated reason for its decision is pretextual." 490 U.S. at 247 n.12.

111. See id. (distinguishing between "pretext" and "mixed-motive" and using "Burdine" synonymously with "pretext"). 
falsity-of-proffered-reason method requires the plaintiff to prove at least that the reasons proffered by the defendant were not motivating factors in the decision. ${ }^{12}$

The plurality's narrow view of the scope of the McDonnell Douglas framework can be explained in part by its use of the term "pretext." The McDonnell Douglas Court used the term "pretext" to refer to the final stage of the framework, where the plaintiff must prove either that the defendant's proffered reason was false or that an impermissible factor more likely motivated the decision. ${ }^{113}$ This use of the term "pretext" was logical in McDonnell Douglas because both methods of proof necessarily showed that the defendant's proffered reason was false. Under the falsity-ofproffered-reason method of proof, this was done by directly proving the proffered reason false. Under the alternate general civil method this was done by inference; if an impermissible factor "more likely motivated" the adverse decision, then by imference the proffered reason did not. The Price Waterhouse plurality's modification of this method did not necessarily produce the same inference. Rather, it required only that the plaintiff prove that an impermissible factor was one motivating factor for the adverse decision. Under the motivating-factor method, therefore, the plaintiff can establish liability without proving, either directly or by inference, that the defendant's proffered reason is false.

Once the Price Waterhouse plurality modified the general civil method of proof to require the plaintiff to show an impermissible factor was one factor which motivated the defendant, the label "pretext" no longer logically applied to the overarching framework. Instead, it applied only to the falsity-of-proffered-reason method of proof. The plurality's use of the term "pretext" to apply to the overarching McDonnell Douglas framework thus unnecessarily limited the franework to methods of proof that prove the proffered reason false.

This limited view of the framework on the part of the Price Waterhouse plurality inevitably led to confusion, for by failing to recognize that the falsity-of-proffered-reason method and motivating-factor inethod coexist within the McDonnell Douglas franework, the plurality was compelled to provide some distinction between the two types of cases. That distinction, according to the plurality, turns on the number of notives that motivated the defendant. ${ }^{114}$ This is a nonsensical distinction. Few decisions are motivated solely by one factor. ${ }^{115}$ Further, as the Price

112. From there the inference can be drawn that in cases in which the defendant's proffered reason is unworthy of belief, the employment decision was more likely than not motivated by an impermissible factor.

113. See McDonnell Douglas Corp. v. Green, 411 U.S. 792, 804-05 (1973).

114. See Price Waterhouse, 490 U.S. at 247 n.12.

115. See Krieger, supra note 64 , at 1223 (explaining that numerous biases and motives, both conscious and subconscious, enter into most decisions). 
Waterhouse plurality itself recognized, Title VII requires that "gender must be irrelevant to employment decisions." 116 Accordingly, even those cases in which the plaintiff proves discrimination by proving the proffered reason false, the necessary inference is not that the defendant was solely motivated by an impermissible factor, but that the defendant was not motivated by the proffered factor. Nonetheless, this fatal flaw in the plurality's analysis led to disorder, for the lower courts were left with little to guide them in distinguishing between a "pretext" case in which the Price Waterhouse plurality indicated the McDonnell Douglas framework applied, and a "mixed motive" case in which the Price Waterhouse plurality erroneously indicated the McDonnell Douglas framework did not apply. As a result, lower courts latched on to the requirement of "direct evidence" articulated, but not sufficiently defined, by Justice O'Connor in her concurrence.

Such a disastrous outcoine might have been avoided if the plurality in Price Waterhouse had taken its assertion that the decision was not a departure from precedent ${ }^{117}$ to the logical conclusion: Price Waterhouse is not a departure from McDonnell Douglas because it works within the same framework. The motivating-factor inethod of proof modifies the earlier general civil method, but it does not depart from the overall McDonnell Douglas framework. As illustrated above, the Court in McDonnell Douglas recognized an alternate model of proof to the falsity-of-proffered-reason method. Accordingly, an articulation of that alternate method does not depart from prior law; it simply clarifies the alternate method of proof that had always existed within the McDonnell Douglas framework.

\section{The Distinction Between Direct and Circumstantial Evidence}

\section{Determines Application of the McDonnell Douglas Framework}

Because the McDonnell Douglas framework encompasses both the falsity-of-proffered-reason method and the motivating-factor method of proof, there is no need to impose a direct evidence requirement for a motivating-factor analysis. Further, not only is direct evidence unnecessary, it is wholly inappropriate. The distinction between direct and circumstantial evidence is relevant only in determining whether the McDonnell Douglas framework applies at all, not in determining which method of proof will be used within that framework.

The framework presented in McDonnell Douglas applies to cases in which the plaintiff does not have direct evidence of discrimination. ${ }^{118}$ If the

116. Price Waterhouse, 490 U.S. at 240.

117. See id. at 248.

118. See Trans World Airlines v. Thurston, 469 U.S. 111, 121 (1985) ("The shifting burdens of proof set forth in McDonnell Douglas are designed to assure that the plaintiff [has] his day in court despite the unavailability of direct evidence.") (alteration in original) (citation omitted); International Brotherhood of Teamsters v. United States, 431 U.S. 324, 358 n.44 (1977) (noting that "the McDonnell Douglas formula does not require direct proof of discrimination"). 
plaintiff offers sufficient direct evidence of discrimination, the McDonnell Douglas franework will be unnecessary. ${ }^{119}$ As discussed above, direct evidence is evidence which, if believed, resolves a matter in issue. ${ }^{120}$ As such, direct evidence does not require any inferences beyond that the evidence be believed. ${ }^{121}$ Evidence of a facially discriminatory oral or written policy is considered direct evidence of discrimination. ${ }^{122} \mathrm{~A}$ written or oral statement made by the adverse decision maker stating his reasons for the decision might also be direct evidence of discrimination. ${ }^{123}$ In these cases the critical issue becomes not whether the evidence adds up to a showing of discrimination, but whether the employer can establish an available defense. ${ }^{124}$ However, facially discriminatory policies and "smoking gun" evidence are not usually available to disparate treatment plaintiffs. ${ }^{125}$ Instead, inost plaintiffs seek to prove disparate treatment discrimination through circumstantial evidence and inferences. It is these cases in which the

119. See Trans World Airlines, 469 U.S. at 121 ("[T]he McDonnell Douglas test is inapplicable where the plaintiff presents direct evidence of discrimination.").

120. See McCormicK ON EvidencE § 185, at 339 (John William Strong ed., 4th ed. 1992).

121. See id.

122. See Trans World Airlines, 469 U.S. at 121 (treating a policy, whicl made the method of transfer available to a disqualificd captain dependent on age, as direct evidence of a violation of the Age Discrimination in Employment Act); see also City of Los Angeles Dep't. of Water \& Power v. Manhart, 435 U.S. 702, 705 (1978) (treating a policy requiring that female employees make larger contributions to a pension fund as direct evidence of discrimination); Grant v. Hazelett Strip-Casting Corp., 880 F.2d 1564, 1569 (2d Cir. 1989) (holding that a memorandum in which the company president stated that he wanted to hire a young man between the ages of thirty and forty constituted direct evidence of discrimination).

123. For example, the defendant's hiring chair miglit state: "We decided not to hire [the plaintiff] because she is Asian." This type of direct evidence is extremely rare. See, e.g., Burns v. Gadsden State Community College, 908 F.2d 1512, 1518 (11tli Cir. 1990) (holding that a college president's statements that women would not be considered for the dean's position constituted direct evidence that the plaintiff's gender played a motivating part in the defendant's refusal to lire lier). Even with evidence like that presented in Burns, a fact finder must still infer that the particular plaintiff was denied the dean's position based on her gender. More frequent is evidence of statements of bias on the part of a decision maker. See, e.g., Weaver v. Casa Gallardo, Inc., 922 F.2d 1515, 1522 (11th Cir. 1991) (racially offensive comments by the company vice president supported the district court's finding that the employer's explanation for promoting its white manager instead of a black manager was pretextual).

124. See, e.g., International Union, UAW v. Johnson Controls, Inc., 499 U.S. 187 (1991) (defending a facially discriminatory policy of refusing to place women in jobs with lead exposure on the basis of the bona fide occupational qualification defense). The bona fide occupational qualification defense is codified in section 703(e) of Title VII. Section 703(e) provides in pertinent part:

Notwithstanding any other provision of this subchapter... it shall not be an unlawful employment practice for an employer to hire and employ employees... on the basis of ... religion, sex, or national origin in those certain instances where religion, sex, or national origin is a bona fide occupational qualification reasonably necessary to the normal operation of that particular business or enterprise. 42 U.S.C. $\$ 2000 \mathrm{e}-2(\mathrm{e})$ (1994).

125. See United States Postal Serv. Bd. of Governors v. Aikens, 460 U.S. 711, 716 (1983) (recognizing that '[t]here will seldom be 'eyewitness' testimony as to the employer's mental processes"). 
McDonnell Douglas framework applies. ${ }^{126}$

Surprisingly, the Court has repeatedly failed to make clear that the McDonnell Douglas framework applies only to cases in which the plaintiff relies on circumstantial evidence of discrimination. ${ }^{127}$ This lack of clarity on the part of the Court is at least partially responsible for lower court reliance on an ill-defined direct evidence requirement for mixed-motives analysis after Price Waterhouse. By failing to explain the applicability of the McDonnell Douglas framework in terms of direct and circumstantial evidence of discrimination in the strict evidentiary sense, the Court opened the notion of direct evidence to a broader application. As a result, when lower courts after Price Waterhouse were searching for a way to distinguish between "pretext" and "mixed-motive" cases, they were willing to adopt a "direct evidence" requirement. Because direct evidence of discrimination in the evidentiary sense is so rare, the courts then stretched the meaning of "direct evidence" to include some types of circumstantial evidence.

Justice O'Connor's concurrence in Price Waterhouse illustrates the confusion surrounding a "direct evidence" requirement. The Justice correctly points out that the McDonnell Douglas framework applies only in those cases where the plaintiff relies on circumstantial evidence of discrimination. ${ }^{128}$ She proceeds nonetheless to require a plaintiff seeking to use the Price Waterhouse method of proof to present "direct evidence that decisionmakers placed substantial negative reliance on an illegitimate criterion in reaching their decision." ${ }^{\text {"129 }}$ What she fails to recognize, at least explicitly, is that to meet this requirement a plaintiff's evidence would have to consist of a statement by the decision maker that he relied on an impermissible factor in making his decision. Therefore, if one adopts Justice O'Connor's view, the motivating-factor method of proof will rarely be available. She recognized this fact only by implication, by stretching her definition of direct evidence to include some circumstantial evidence. The most telling indicator of Justice O'Connor's enlarged defimition is her conclusion that the plaintiff im Price Waterhouse presented direct evidence of discrimination..$^{130}$ In fact, the evidence that Justice O'Connor described as

126. See id. at $714 \mathrm{n} .3$ (agreeing with the court of appeals that the plaintiff should not be required to submit direct evidence of discriminatory intent); International Brotherhood of Teamsters v. United States, 431 U.S. 324, 358 n.44 (1977) (noting that "the McDonnell Douglas framework does not require direct proof of discrimination").

127. See, e.g., St. Mary's Honor Ctr. v. Hicks, 509 U.S. 502 (1993); Texas Dep't of Comununity Affairs v. Burdine, 450 U.S. 248 (1981); Furneo Constr. Corp. v. Waters, 438 U.S. 567 (1978); McDonnell Douglas Corp. v. Green, 411 U.S. 792 (1973).

128. See Price Waterhouse v. Hopkins, 490 U.S. 228, 271-72 (1989) (O'Connor, J., concurring) ("As should be apparent, the entire purpose of the McDonnell Douglas prima facie case is to compensate for the fact that direct evidence of intentional discrimination is hard to come by.").

129. Id. at 277.

130. See id. 
"direct" consisted of comments on evaluation forms suggesting that Hopkins "overcompensated for being a woman" and advising that she take "a course at charm school," and of a recommendation by the partner responsible for delivering the board's decision to Hopkins that she should "walk more femininely, talk more femininely, dress more femininely, wear Inake-up, have her hair styled, and wear jewelry." " Although this may be highly probative circumstantial evidence of discrimination, it remains circunstantial evidence because it requires the fact finder to infer that these sex-based attitudes infected the partnership decision. ${ }^{132}$

It seems more likely that Justice O'Connor did not intend to implement a requireinent of direct evidence at all; rather, she likely intended to require a plaintiff to produce strong evidence of intentional discrimination, whether circumstantial or direct. Even a requirement of strong evidence, however, is untenable, particularly in light of the 1991 Act. Justice O'Connor's evidentiary requirement rests on her concern about abandoning but-for causation in Title VII. According to Justice O'Connor, to establish liability under Title VII, a plaintiff must establish that "but for" the einployer's reliance on an impermissible factor, the adverse decision would not have been made. ${ }^{133}$ However, not only was Justice O'Connor's concern about but-for causation not shared by the plurality in Price Waterhouse, ${ }^{134}$ it was explicitly rejected by the Civil Rights Act of 1991, which places liability on the einployer even if it can show that it would have made the same decision anyway. ${ }^{135}$ There is simply no remaining justification, therefore, for maintaining a heightened threshold evidentiary requirement for plaintiffs seeking to use the inotivating-factor method of proof, and continued lower court reliance on such a requirement is misplaced.

\section{B. The 1991 Act and the Proposal}

The 1991 Act also lends support to an overarching frainework with two coexistent methods of proof, both of which are available regardless of the type of evidence presented. Congress did not clearly address the applicability of section 107 of the Civil Rights Act of 1991 to particular

131. Id. at 235 .

132. For additional analysis of Justice O'Connor's definition of direct evidence, see Charles Sullivan, Accounting for Price Waterhouse: Proving Disparate Treatment Under Title VII, 56 BrooK. L. REv. 1107 (1991) and Steven M. Tindall, Do As She Does, Not As She Says: The Shortcomings of Justice O'Connor's Direct Evidence Requirement in Price Waterhouse v. Hopkins, 17 BERKELEY J. EMP. \& LAB. L. 332 (1996).

133. See Price Waterhouse, 490 U.S. at 263 (O'Connor, J., concurring).

134. See id. at 240 ("To construe the words "because of' as colloquial shorthand for 'but-for causation'... is to misunderstand them.").

135. See Civil Rights Act of 1991, Pub. L. No. 102-166, § 107, 105 Stat. 1075 (codified at 42 U.S.C. $\$ 2000 \mathrm{e}-5(\mathrm{~g})(2)(B)(1994)$ ) (imposing liabihty upon showing that an impermissible factor was a motivating factor in the decision, but foreclosing certain remedies upon the defendant's showing that it would have taken the same action anyway). 
disparate treatment claims. As a result, as noted above, section 107 has been interpreted inconsistently by the lower courts, many of which maintain some requirement of "direct" evidence before applying section $107 .{ }^{136}$ Failing to understand the overall McDonnell Douglas frainework, these courts cling to a direct evidence requirement without justification.

The plain language of the Act reveals no intention on the part of Congress to limit section 107 to those cases in which the plaintiff has presented direct evidence. ${ }^{137}$ In fact, the Act makes no distinction between direct and circumstantial evidence. Instead, it simply states that "an unlawful employment practice is established when the coinplaining party demonstrates that race, color, religion, sex, or national origin was a motivating factor for any employment practice, even though other factors also unotivated the practice."138 Further, as one commentator has noted, the section's use of the terms "complaiming party" and "deinonstrates" in section 703(m) and "respondent" in section 706(g)(2) links the two sections to section 104 of the 1964 Act, which provides definitions for all Title VII cases. ${ }^{139}$ Thus, from the plain language of the Act, it appears that sections $703(\mathrm{~m})$ and $706(\mathrm{~g})(2)$ of the annended Civil Rights Act were intended to apply to all Title VII disparate treatment claims.

In addition, the Act's stated purpose and its legislative history suggest a broad application of the section. Congress enacted the Civil Rights Act of 1991 to reverse a series of plaintiff-hostile decisions on the part of the Supreme Court. ${ }^{140}$ In its House Report, Congress explained:

The impact of the [Price Waterhouse] decision is particularly profound because the factual situation at issue in Price Waterhouse is a common one. As the Justice Department correctly observed, "[v]irtually every Title VII disparate treatment case will to some degree entail inultiple inotives." If Title VII's ban on discrimination in einployinent is to be meaningful, victims of proven discrimination inust be able to obtain relief, and perpetrators of discrimination must be held liable for their actions. ${ }^{141}$

Taking this purpose into account, it is difficult to argue that Congress

136. See supra notes $79-85$ and accompanying text.

137. See Civil Rights Act of 1991, Pub. L. No. 102-166, § 107, 105 Stat. 1075 (codified at 42 U.S.C. $\$ 2000 \mathrm{e}-2(\mathrm{~m}), 2000 \mathrm{e}-5(\mathrm{~g})(2)(\mathrm{B})(1994))$.

138. Id.

139. See Michael J. Zimmer, The Emerging Uniform Structure of Disparate Treatment Discrimination Litigation, 30 GA. L. REv. 563, 601 \& nn.136-37 (1996).

140. See Civil Rights Act of 1991, Pub. L. No. 102-166, \& 3, 105 Stat. 1071 (codified at 42 U.S.C.A. $\S 1981$ note (West 1994) (stating one of the purposes of the act: to "respond to recent decisions of the Supreme Court by expanding the scope of relevant civil rights statutes in order to provide adequate protection to victims of discrimination").

141. H.R. REP. No. 102-40(I), at 47 (1991), reprinted in 1991 U.S.C.C.A.N. 549, 585 (citation omitted). 
intended to place a threshold requirement of direct or even strong evidence of discrimination on the section's applicability. It seems highly unlikely that Congress overruled the motivating-factor method as stated in Price Waterhouse to make it easier for plaintiffs to establish liability, yet also intended to retain a severely limiting test for the method's application.

Nonetheless, circuit courts have held fast to a direct evidence requirement since the 1991 Act. A look at the analyses of several of the circuits that have ruled on the applicability of sections $703(\mathrm{~m})$ and $706(\mathrm{~g})(2)(B)$ of Title VII illustrates the profound effect of Congress's, as well as the Court's, failure to clarify the doctrine.

In Fuller v. Phipps, the Fourth Circuit, after extensive discussion, held that section 703(m) applies only in those cases in which the plaintiff has presented "sufficiently direct evidence of discrimination." 142 The Fuller court attempted to justify this conclusion in three ways, each of which fails to withstand scrutiny. It first asserted that the Supreme Court has "indicated as much," citing to the Supreme Court's statement in Landgraf that "section 107 'responds to Price Waterhouse ... by setting forth standards applicable in "mixed motive" cases." 143 This comment was made by the Landgraf Court in dicta, however, without any further discussion. ${ }^{144}$ Moreover, as noted earlier, the statement fails to reveal any indication that the Court finds a "mixed notive case" synonymous with a "case requiring direct evidence." 145

The Fuller court also relied on the plain language of the statute as support for its interpretation. It pointed to the last phrase of section 703(m) - "other factors also motivated the practice"-as evidence that the Act requires direct evidence of discrimination. ${ }^{146}$ It reasoned that this language indicated congressional intent to distinguish between the methods of proof based on the number of motives alleged. As discussed earlier, however, such a distinction is nonsensical. Moreover, the phrase does not indicate a direct evidence requirement; it simply clarifies that the motivatingfactor method contemplates employer liability even when the employer was also motivated by legitimate factors. ${ }^{147}$

Finally, the Fuller court relied on the legislative history of the 1991 Act, which, in its opinion, "ma[de] evident that Congress sought to alter the standards of liability in mixed-motive cases." ${ }^{\prime 48}$ The Fuller court cited

142. Fuller v. Phipps, 67 F.3d 1137, 1141 (4th Cir. 1995).

143. Id. at 1143 (quoting Landgraf v. USI Film Products, 511 U.S. 244, 251 (1994)).

144. See Landgraf, 511 U.S. at 251.

145. See supra Section I.B.2. For a thorough analysis of the origin of the term "mixed motive" and criticism of the Fuller decision, see Allen v. City of Athens, 937 F. Supp. 1531, 1540-42 (N.D. Ala. 1996).

146. Fuller, 67 F.3d at 1144.

147. For another author making this same point, see Zimmer, supra note 139, at n.137.

148. Fuller, 67 F.3d at 1144. 
to a portion of the House Report that discussed the need to overturn Price Waterhouse. ${ }^{149}$ The Fuller court failed to note, however, that the House Report never mentions "direct evidence;" 150 nor does the House Report reference any evidentiary requirement for the application of section 107, other than to note that conduct or statements are relevant under the motivatingfactor method only if the plaintiff shows a nexus between the conduct or statements and the employment decision at issue. ${ }^{151}$ Instead, the House Report focuses on the need to prevent discrimination in the work force and on the detrimental effect of permitting an employer who relied on discriminatory reasons for its decision to escape liability simply because legitimate factors also played a part. ${ }^{152}$ The legislative history thus neither explicitly nor implicitly requires an evidentiary threshold for a plaintiff's use of the motivating-factor method of proof.

Although following an altogether different interpretation of the 1991 Act, the Second Circuit's approach is indicative of the confusion surroundimg disparate treatment jurisprudence, even among those courts that seek to permit plaintiffs to use the motivating-factor method of proof. The Second Circuit retains a "direct evidence" requirement, but only for what it calls the "same-decision instruction" of section 706(g)(2). In Fields v. New York State Office of Mental Retardation and Developmental Disabilities, the Second Circuit explained that the motivating-factor instruction of section 703(a)(1) is available in all cases. ${ }^{153}$ However, it went on to find that section $706(\mathrm{~g})(2)(B)$ applies only where the plaintiff has relied on direct evidence or evidence that is "directly tied" to the alleged discrimination. ${ }^{154}$ By clinging to a direct evidence requirement, the court undermined its own rationale. The court's conclusion that the "same-decision instruction" was only allowed upon a showing of direct evidence conflicts with the plain language of the statute. Section 706(g)(2) of Title VII states that it applies

149. See id.

150. See H.R. REP. No. 102-40(1) (1991), reprinted in 1991 U.S.C.C.A.N. 549, 583-87.

151. See id. at 586.

152. See id. ("The inevitable effect of the Price Waterhouse decision is to permit prohibited employment discrimination to escape sanction under Title VII."); see also id. at 585-86 ("Legislation is needed to restore Title VII's comprehensive ban on all impermissible consideration of race, color, religion, sex or national origin in employment.").

153. See Fields v. New York State Office of Mental Retardation and Developmental Disabilities, 115 F.3d 116, 120-21 (2d Cir. 1997), in which the court explained:

[A] Title VII plaintiff can prevail by proving that an impermissible faetor was a 'motivating factor,' without proving that the employer's proffered explanation was not some part of the employer's motivation....

... Since a plaintiff prevails by showing that discrimination was $a$ motivating faetor, it can invite the jury to ignore the defendant's proffered legitimate explanation and eonclude that discrimination was a motivating factor, whether or not the employer's proffered explanation was also in the employer's mind.

154. See id. at 124 \& n.4 (stating that the "mixed motives" charge is "just shorthand for seeking an additional instruction concerning the defendant's affirmative defense" and requiring direct evidence for such a charge). 
"[o]n a claim in which an individual proves a violation under section 2000e-2(m)." 155

Both the Fuller and the Fields opinions reflect the dire consequences of the Court's, as well as Congress's, failure to clarify the doctrine. Each court wrestled with the conflict between the limited view of the McDonnell Douglas framework put forward by the Price Waterhouse plurality and evidence that the 1991 Act provides the motivating-factor niethod of proof in all cases. The Fuller court reconciled the conflict by finding that the two methods of proof must be distinguished on the strength of the evidence presented by the plaintiff. The Fields court, on the other hand, appeared to understand that the motivating-factor method of proof must be available to the plaintiff in all cases, but ultimately undermined its own reasoning by adopting a doctrine that is in direct conflict with the plain language of the statute. Each court retamed a direct evidence requirement because it failed to understand the scope of the McDonnell Douglas framework. ${ }^{156}$ Once it is understood that the McDonnell Douglas framework includes both the falsity-of-proffered-reason method of proof and the inotivating-factor inethod of proof, however, the direct evidence requirement must be abandoned altogether.

\section{Practical Considerations and the Proposal}

Finally, this Comment's proposal makes practical sense. It retains the benefits of the McDonnell Douglas prima facie showing for all cases based on circunistantial evidence. Further, it allows the plaintiff the flexibility to choose between proving discrimination by showing that an illegitimate factor motivated the decision maker or proving intent to discriminate based on a showing that the defendant's proffered reason is false and a cover-up for discrimination. Moreover, it reflects the understanding that Title VII prohibits eniployment decisions based on imperimissible factors, even where permissible factors also played a part in the decision.

Because the notivating-factor method falls within the McDonnell Douglas framework, both parties will benefit from the prima facie case requirement. As noted above, the requirement of a prima facie case

155. 42 U.S.C. $\$ 2000 \mathrm{e}-5(\mathrm{~g})(2)(\mathrm{B})(1994)$.

156. The Fuller court clearly saw the McDonnell Douglas framework as necessarily distinct from the "mixed-motive" method of proof. See Fuller, 67 F.3d at 1142 (indicating concern that without a direct evidence requirement for a "mixed-motive" instruction, the two categories of cases would be "conflated"). The Fields court, on the other hand, seemed to cling to a direct evidence requirement in part out of hesitancy to break from prior decisions. See Fields, 115 F.3d at 122 (construing earlier circuit opinions requiring direct evidence as applying only to the applicability of a defendant's samedecision defense). The Fields court purported to comply with earlier decisions by requiring direct evidence, but it defined "dual motivation" narrowly so that the requirement only applied to the section $706(\mathrm{~g})(2)$ instruction. The Fields court therefore migbt be seen as understanding the scope of the McDonnell Douglas framework, but lacking the necessary conviction to defy earlier decisions to the contrary. 
benefits the defendant by filtering out those plaintiffs' cases that do not eliminate the most common reasons for the decisions. On the other hand, it serves the plaintiff by triggering a legal presumption of discrimination to which the defendant must respond. And finally, it provides plaintiffs with an inferential method of proof which stems from the defendant's proffered reason while retaining an inferential method of proof which does not stem from the defendant's proffered reason but rather proves discrimination directly by showing that an impermissible factor was a motivating factor in the decision.

Admittedly, the utility of the McDonnell Douglas framework with its prima facie case and required response may be diminished by the implementation of modern discovery rules. In her piece, The Last Minuet: Disparate Treatment After Hicks, ${ }^{157}$ Professor Deborah C. Malamud argues that the McDonnell Douglas framework has been reduced to an "empty ritual" and calls for its abandonment. ${ }^{158}$ Analyzing district court use of the framework at the pretrial stage, she lays out an impressive case that the McDonnell Douglas framework does nothing the normal rules of civil procedure cannot do. ${ }^{159}$ Despite the strength of her criticisms, however, Professor Malamud relies on the same assumption on which the plurality in Price Waterhouse relied; she sees the McDonnell Douglas framework as synonymous with the falsity-of-proffered-reason method of proof. ${ }^{160}$ This limited view of the scope of the framework tends to skew both her evaluation of the framework's utility and her appraisal of alternatives. ${ }^{161}$ In the end, she is forced into a solution that retains only the motivating-factor method of proof, to the detriment of those plaintiffs whose cases might have been stronger using the falsity-of-proffered-reason method under Hicks. ${ }^{162}$

157. Malamud, supra note 35.

158. See id. at 2237-38. Professor Malamud argues for sweeping reform of disparate treatment jurisprudence, seeking to throw out both the McDonnell Douglas framework and the falsity-ofproffered-reason method of proof. The solution provided here, in contrast, works within established law. By making sense of disparate treatment jurisprudence as it has been established, the proposal presented here offers immediate respite from the current confusion and a coherent framework from which to evaluate and litigate claims of disparate treatment in the workplace.

159. See id. at 2275-323.

160. See id. at 2320-22 (discussing the problems of distinguishing between "two special proof structures": the McDonnell Douglas framework and what Professor Malamud calls the "mixed motive" framework); see also id. at $2229 \mathrm{n} .3$ (explaining the motivating-factor method of proof as a "special proof structure . . . which applies to some individual intentional discrimination cases in which multiple motives for the adverse decision are proven").

161. For example, Professor Malamud expresses concern that without a direct evidence requirement for a plaintiff's use of the motivating-factor method, the motivating-factor and falsity-ofproffered-reason methods of proof will be difficult to distinguish. See id. at 2322. This is the same concern expressed by Justice O'Connor in Price Waterhouse, and, as discussed above, is unjustified. The two methods of proof are distinguishable: One flows through the defendant's proffered reason and the other does not. See supra notes 98-100 and accompanying text.

162. See Malamud, supra note 35, at 2322 \& n.291. 
The proposal presented here provides plaintiffs with the option of proving discrimination through the defendant's proffered reason. A plaintiff with strong evidence that the defendant's proffered reason is false, but weak evidence of discriminatory animus might be more successful using the falsity-of-proffered-reason method. This plaintiff will be entitled to all reinedies outlined in the 1991 Act for Title VII violations. In contrast, a plaintiff with strong evidence of discriminatory animus, but little-to-no evidence that the defendant's proffered reason is false, would likely be more successful arguing under section 703(m) that the decision was motivated in part by an impermissible factor. Although liability would then be established, this plaintiff, under section $706(\mathrm{~g})(2)$, might be required to refute the defendant's claim that it would have made the same decision anyway before she is entitled to all forms of remedy. The proposal thus provides the parties with flexibility to tailor their claims depending on the strengths and weaknesses of available evidence.

The proposal also benefits the parties to the suit by giving thein a basis from which to evaluate the claim. As it stands now, it is difficult, if not impossible, for the parties to determine at the outset of a case whether the court will consider a plaintiff's evidence "direct" enough to warrant a section 703(m) instruction. Under the proposal presented here, however, as long as the plaintiff can establish a prima facie case under McDonnell Douglas and present evidence sufficient to survive summary judgment, she will be entitled to a section 703(m) jury instruction. This certainty that the motivating-factor analysis is always available allows both parties to evaluate the case prior to trial.

One might argue that the proposal, by retaining both methods of proof as alternate methods, is too confusing for a jury. ${ }^{163}$ The Eighth Circuit seems to have taken this approach in its model jury instructions. ${ }^{164}$ However, the falsity-of-proffered-reason method of proof should be retained as an option for plaintiffs for several reasons. First, there is no evidence that either the Supreme Court or Congress intended the falsity-of-profferedreason method of proof to be eliminated. Second, as discussed above, the

163. Prior to the 1991 Act, disparate treatment claims were decided by a judge. Under the new Act, however, a jury is available on all claims for which the plaintiff requests damages. See Civil Rights Act of 1991, § 102, 42 U.S.C. \& 1981a(c) (1994).

164. See Manual of Model Civil Jury Instructions for the District Courts of the Eighth Circuit § 5, Employment Cases Element and Damage Instructions (1992). The Federal Jury Instructions, modeled in significant part on the Eighth Circuit instructions, also seem to adopt this view. See 5 LEONARD B. SAND ET AL., MODERN FEDERAL JURY INSTRUCTIONS \& 88.04(3) (1996).

Professor Malamud has taken this position even further by calling for abandonment of the McDonnell Douglas framework altogether. See Malamud, supra note 35, at 2310-21. Professor Malamud raises valid concerns about the McDonnell Douglas framework promoting "misplaced concreteness" and discouraging the kind of "hohistic factfinding" that might be most likely to reveal the truth about discrimination in the workplace. As noted above, however, her position is premised in part on the view that the motivating-factor method of proof and McDonnell Douglas framework are mutually exclusive. See supra notes 160-162 and accompanying text. 
falsity-of-proffered-reason method of proof provides plaintiffs with an option when their available evidence centers most strongly on the phony nature of the defendant's proffered reason. Third, eliminating the falsity-of-proffered-reason method of proof might promote confusion as to the scope of the McDonnell Douglas framework. Retaining two methods of proof within the overarching McDonnell Douglas framework makes clear that the framework is not synonymous with any one method of proof, and leaves the door open for additional methods of proof from which inferences of discrimination may be drawn. Moreover, a plaintiff is not required to proceed under both methods of proof. If a plaintiff believes that a jury instruction consisting of both methods is unduly confusing, he may choose to proceed under one method or the other. The available methods of proof simply provide options for proving disparate treatnent through circumstantial evidence and inference. Only where a plaintiff fails to introduce evideuce sufficient to reach the fact fimder on one theory or the other will a plaintiff's options be restricted.

Finally, the proposal recognizes that decisions are alnuost always based on a number of factors, both conscious and unconscious. ${ }^{165}$ Title VII promotes equality in the workplace by providing that a person's protected group status must be irrelevant to employment decisions. Accordingly, if an illegitimate factor played a motivating part in an adverse entployment decision, Title VII has been violated. Similarly, if the employer's proffered reason is shown to be a false cover-up for an illegal motivating factor, Title VII has been violated. The proposed frainework provides plaintiffs with a method of proof that is not dependent on proving that the employer's reason is phony. At the same time, it retains a presumption that where the employer's reason is proved to be false, an illegitimate factor is likely to have played a part in the decision.

\section{CONCLUSION}

Disparate treatment jurisprudence stands today in a state of unnecessary chaos where the outcome of cases may be determined by the happenstance of conflicting analyses rather than by the merits of the claim. Much of the overt racism that groups faced in 1964 when the Civil Rights Act was first enacted is close to extinction. In its place, the more subtle forms of discrinination persist. The Snpreme Court created the McDonnell Douglas framework to aid parties and courts in litigating these less obvious

165. See Krieger, supra note 64, at 1164-65 (arguing that current disparate treatment jurisprudence does not recognize that categorization based on an illegitimate factor may distort perccption and that at the moment of decision, an employer may be entirely unaware of the effect of an employee's group membership on the decisionmaking process). Professor Krieger warns that we should understand the term "motivating factor" as a synonym of "actuating factor" and should not conflate motivation and intentionality. See id. at 1243. 
claims of disparate treatment in the workplace. It should remain an aid, not a hindrance. The overarching framework, as well as the methods of proof within that framework, are tools to be used in identifying the more common forms of discrimination today. They have proven to be flexible to the changing understanding of the nature of discrimination and should so remain, for discrimination itself is hardly a static beast. 
